УДК 182-161:1

Ковпік C. I. доктор філологічних наук, професор кафедри української та світової літератур Криворізький педагогічний інститут ДВНЗ «Криворізький національний університет»

\title{
КОПЛЕКС ФАНАБЕРА ЯК ВИЩА ФОРМА АНТИДУХОВНОСТІ
}

У статті досліджено психотип фанабера, який яскраво розкривається у творах украӥнської літератури, простежено історію формування фанаберства, виявлено особливості комплексу фанаберства та його антидуховну наснаженість. Авторка статті 
відзначила, що зарозумілість, надмірно висока думка про себе - $і$ в зв'язку з цим зневажливе ставлення до інших або ж бундючність, пиха, чванство обертаються, насамперед, злом для носія усіх вище зазначених негативних рис. Причиною розвитку фанаберства є прорахунки батьків у вихованні дітей.

Ключові слова: психотип, фанабер, комплекс, антидуховність.

В статье исследуется психотип фанабера, который ярко раскрывается в произведениях украинской литературы, а также исследована история формирования фанаберии, выявлень особенности комплекса фанабера и его антидуховную сущность. Автор статьи отметила, что чрезвычайно высокая оценка самого себя, и в этой связи пренебрежительное отношение к другим, оказывают негативное влияние, прежде всего на самого носителя указанных черт. Причина развития фанаберства кроется в серьезных недостатках допущенных родителями в воспитании детей.

Ключевые слова: психотип, фанабер, комплекс, антидуховность.

The article studied the psychotypefanaberia whichwas clearly revealed in the works of Ukrainian literature, also the history of the formation of fanaberiawas studied, the peculiarities of the complex «fanaberia», and its anti-spiritual nature were identified. The author noted that one's own conceit, and therefore contemptuous attitude to others, has a negative impact, primarily on the holder of these features. The formationof fanaberia development is reasoned to consist of serious shortcomings committed by parents in the upbringing of their children.

Keywords: psychotype, fanaberia, complex, anti-spiritual.

Минуло майже десять років з часу виходу у науковий світ монографії А. В. Козлова «Духовність як літературознавча категорія» (2005), в якій автор чи не вперше у вітчизняному літературознавстві обгрунтував сутність душі, духу та духовності персонажів твору літератури, пояснив значущість вивчення духовного потенціалу твору літератури в школі й у виші.

Як засвідчили численні наукові праці літературознавця після виходу його монографії, літературознавча категорія «духовність» стала постійно перебувати у центрі його наукових інтересів, а іï зміст доповнювали нові наукові розвідки. У категоріальному апараті вченого під час аналізу думок, слів, вчинків персонажів творів літератури з точки зору антидуховності постійно зверталась увага на такі риси персонажів, як: честолюбство, самозакоханість, зневажливе ставлення до інших та ін., котрі нині у психології складають основу психологічного комплексу фанабера.

Так, «Психологічна енциклопедія» автора-упорядника О. М. Степанова фанаберство (виокремлення жирним шрифтом наше - К. С.) тлумачать у такий спосіб: «(польське. fanaberia - зарозумілість, чванство) - негативна риса характеру людини, яка проявляється в зарозумілому, погордливому, чванливому 
ставленні до інших людей. Причиною виникнення фанаберства є серйозні прорахунки у вихованні дитини. У дорослому віці фанаберство майже не піддається перевихованню. Водночас пиха, чванливість, примхи стають причиною конфліктних ситуаиій або появи афекту неадекватності» [Психологічна енциклопедія 2007:375]. Як відомо, лексема фанаберія - це яскраво виражений ідишизм, котрий, на думку мовознавців, потрапив у німецьку мову і збігається з деякими відповідниками у ній [Пиц 2013].

Таким чином, мета статті полягає у тому, щоб шляхом аспектного аналізу, спираючись на зміст сформульованого у психології комплексу фанаберства, дослідити психотип персонажа-фанабера у творах української літератури.

Синонімом до фанаберства $є$ зарозумілість, тобто надмірно висока думка про себе - і в зв'язку з цим зневажливе ставлення до інших або ж бундючність, пиха, чванство та ін. Проте фанаберія - це не одна риса характеру людина, а комплекс усіх перерахованих попередньо рис характеру людини, яку проявляються постійно на всіх рівнях свідомої діяльності людини.

Про зверхність як рису характеру мову вів ще грецький філософ Теофораст у своїй праці «Характери». Розкривши сутність близько тридцяти рис характеру людини, він приділив увагу «зверхності», яка нині також $\epsilon$ складовою комплексу фанабера. На думку Теофраста, зверхність - це найвища форма презирства і відповідно вона підкреслює людиноненависницьку сутність людини.

Усі риси комплексу фанабера психологи відносять до набутих, тобто вихованих, придбаних у дитячому або юнацькому віці. Лексема «фанаберія» $\mathrm{i}$ похідні від неї «фанаберний», «фанаберство» активно фігурували і фігурують у творах українських письменників (І. Нечуй-Левицького, М. Старицького, А. Свидницького, І. Франка та ін.). Тобто, вказуючи на фанаберію персонажа письменники так чи інакше одразу визначали його психотип. Адже психотип персонажа - це змодельований письменником зразок, в якому узагальнені риси характеру персонажа, представлені основні форми поведінки, емоції у різних життєвих ситуаціях. 
Так, I. Нечуй-Левицький звертає увагу на причини фанаберії персонажа: «Хіба ж ти не бачищ, щзо син молодий, набрався трохи фанаберії од тих дворянських дітей у школі» [Нечуй-Левицький 1966]; «Хто його зна, де та дітвора такої пихи набирається. Аби тільки в четвертий клас перейшов, то наче не той хлопец̧ь стане: задере носа, щзо куди!» (А. Свидницький).

Сучасні психологи визначили таки типи фанаберії: повітова, княжа, родинна.

У повісті «Князь Сремія Вишневецький» I. Нечуй-Левицький розкрив особливості княжої фанаберії, яка виявилася у князя Сремї Вишневецького в юнацькі роки: «Гордий і неласкавий з старшими й вищими за себе, Сремія був привітний до челяді. Він навіть братався й єднався з челядинцями шляхтичами, але в тому самому братанні було знати якесь потайне глузування, прикрите жартами та смішками...» [Нечуй-Левицький 1966:21].

Така поведінка засвідчує підлість молодого князя, яку він в зрілому віці буде демонструвати відверто й зухвало. Пошуки слави далеко від батьківського будинку носили хворобливий характер у князя Сремії: «I молодому князеві тепер здавалось, щзо він, виїхавщи з батьківського дому, ніби одчалив од берега i пустився на те синє просторне безмежне море шукати щзастя-долі й великої слави, такої слави, щуоб вона затінила славу усіх князів, гетьманів $і$ королів, засліпила увесь світ... щзоб про його ймення та про його славу пройшла чутка од краю до, краю й залунала піснями. Як вона залунала піснями про славні козаџьькі вчинки славного лищуаря Яреми Байди-Вишневецьького» [НечуйЛевицький 1966:86]. У цьому роздумі розкривається одна із провідних рис комплексу фанабера - честолюбність, яка набуваючи егоїстичного спрямування може негативно вплинути на розвиток особистості, що проявляється у відвертому ігноруванні громадських інтересів i наданні переваги своїм бажанням. А далі виплекане честолюбство породжує зарозумілість, пихатість, чванливість: «Мене ніхто не скине з місия, як козаки скидають свойх гетьманів. Україна з гетьманством, з козаками мені не припадає до вподоби. Якась там нікчемна, гидка чорнота, якісь сіромахи будуть надо мною верховодити. Не 
бажається мені стати козацьким гетьманом, яким був мій дід Байда Вишневецький. На козащ̧ьких радах якийсь там Грицьько, якийсь Павлюк крикне тобі в вічі: «Клади булаву!» Якийсь Крутихвіст, якийсь Задериморда скине тебе з гетьманства й видере з твоїх рук булаву. Плюнути мені на такі ради! Не варті вони княжої слини! Я сам візьму свою булаву і ні перед ким не покладу ї̈. Моя гетьманська булава - то землі безмірні, безліч грошей, військо. Он де моя сила! А з ичим я добуду й слави, а може й корони... Це багато вартніше за якусь гетьманську булаву. Козацькі порядки, козацький мужицький уклад противні мені! Я їх ненавиджу» [Нечуй-Левицький 1966:129]. Князівська фанаберія врешті-решт остаточні сформувала в свідомості підлеглих думку про Сремію Вишневецького як про анти духовну особу, а тому після його смерті: «Пішли щзирі прокльони на той світ слідком за його душею од усього украӥнського народу» [Нечуй-Левицький 1966:229].

Інколи зарозумілість, зневажливе ставлення до інших або ж бундючність, пиха, чванство персонажа видаються смішними. Наприклад, смішним виявилось фанаберство Мартина Борулі із однойменної п’єси I. КарпенкаКарого. Його фанаберство стало причиною родинних конфліктів. Оскільки у п’єсі, на жаль, мова про виховання Мартина Борулі не йде, то можна припустити, що комплекс фанабера сформувався у нього в досить зрілому віці.

Про демонстрацію чванливого й погордливого ставлення до інших вів мову в оповіданні «Ложные понятие» Г. Квітка-Основ'яненко. Саме честолюбство стало причиною занедбання Пантелеймоном Стовбиром батьківського капіталу, який йому сину-одинку залишився після смерті батька. Старий Стовбир був поважною людиною за життя, а при ньому син «был скромен... никак не противился его распоряжениям» [Квітка-Основ'яненко 1979:322]. А вже після смерті батька Пантелеймон став відверто демонструвати зверхність і чванливість до інших людей. Він болюче реагував на те, що люди, коли він йшов вулицею не кланялись йому. Від сусідів він вимагав, щоб ті звертались до нього виключно по імені і по-батькові. Пантелеймон всіляко намагався примусити людей поважати себе. Він навіть батьківське прізвище 
«Стовбир» змінив на «Стовбиревський», але й це суттєво не вплинуло на ставлення людей до нього. Усе це призвело врешті-решт до того, що молодий чоловік у гонитві за славою і визнанням втратив усе те, що батько йому залишив у спадок.

А в оповіданні I. Франка «Пироги 3 чорницями» розкривається процес формування родинної фанаберії: від діда до матері, від матері до сина. Так, Хане Гольдбаум «страшно недобродуша мати» [Франко 1978:201], яку усі домашні бояться. Ця жінка запопадлива й гордовита через те, що вона «одинока дочка славного бориславського капіталіста Мойші Шіндера. Такого батька така й дочка» [Франко 1978:201]. Свого єдиного сина Хана наставляла на те, щоб він тримався в школі тих дітей, які краще одягнені, а біля бідняків «не терся». Мати цілеспрямовано розвивала в дитині погордливе ставлення до інших людей. Врешті-решт таке виховання призвело до невростинічного вибуху дитини.

Отже, аналіз лише деяких творів української літератури засвідчив, що незважаючи на причини розвитку комплексу фанабера (виховані та розвинуті) такий психотип персонажа цілеспрямовує свою діяльність на творення зла не тільки іншим, а й самому собі. Честолюбство та пихатість заважає таким психотипам об’єктивно осмислювати свої вчинки, а тому вони можуть навіть втигдядати смішними (Мартин Боруля).

\section{БІБІЛОГРАФІЯ}

Квітка-Основ’яненко 1979 - Квітка-Основ'яненко Г. Зібрання творів у семи томах / Г.Квітка-Основ'яненко. - К. : Наукова думка, 1979. - Т. 4. : Прозові твори ; упорядник і примітки Н.О. Ішиної. - 541 с.

Козлов 2005 - Козлов А. Духовність як літературознавча категорія : монографія / А. Козлов. - Київ : Акцент, 2005. -

Нечуй-Левицький 1966 - Нечуй-Левицький С.Зібрання творів у десяти томах. - К. : Наукова думка, 1966. - Т. 7 : Том сьомий. Прозові твори. - 460 с. 
ПС 2003 - Психологический словарь ; авт.-сост. В. Н. Копорулина, М. Н. Смирнова, Н. О. Гордеева ; под. общ. ред. Ю. Й. Неймера. - Ростов-наДону : Феникс, 2003. - 640 с.

Пиц 2013 - Пиц Т. До історії дослідження німецьких запозичених слів в українській мові / Тараса Пиц // Українська мова. - 2013. - №2. - С.84-98.

СПС 2007 - Современный психологический словарь ; общ. ред. Б. Г. Мещеряков, В. П. Зинченко. - М. : АСТ; СПб. : Прайм-Еврознак, 2007. $490 \mathrm{c}$.

Феофраст 1974 - Феофраст. Характеры /Феофраст ; перевод, статья и примечания Г. А. Стратановского. - Ленинград : «Наука», 1974. - 123 с.

Франко 1978 - Франко I. Зібрання творів у п’ятдесяти томах. Художні твори томи 1-25 / I. Франко. - К. : Наукова думка, 1978. - Т. 16. : Повісті тп оповідання ; упорядкування та коментарі Ф. П. Погребенника. - 510 с. 